\title{
THE EFFECT OF SOIL TEMPERATURE AND MOISTURE CONTENT ON THE THERMAL PROPERTIES OF ISMAILIA SANDY SOIL UNDER ALFALFA COVER
}

\author{
El-Raies, S.A.A.; Amal M. Abdel Tawab; El-Farghal, W.M. \\ and El-Sisi, S.E.M. \\ Soil, Water and Environment Agricultural Research Institute, \\ ARC, Giza, Egypt
} ABESTRACT

Fifty one registers (one every week) of soil temperatures in 51 weeks through twelve months from January to December were recorded for every depth. They were recorded for three soil depths $(0.05,0.15$, and $0.30 \mathrm{~m})$ in sandy soil that covered with alfalfa plants in Ismailia Agriculture Research Station of Ismailia governorate. The total soil temperature registers recorded were (51 observations x 3 depths) 153 readings. One hundred and fifty three soil samples in the same 51 weeks were collected from the same locations of the three depths. The volumetric heat capacity, thermal conductivity and thermal diffusivity were calculated. The obtained results were summarized as follows:

Soil volumetric heat capacity increased with increasing moisture content at the nearest soil surface depth $(0.05 \mathrm{~m})$ or the deepest one $(0.30 \mathrm{~m})$. They ranged from 1.345479 to 1.803934 , 1.286049 to 1.678707 and from 1.281804 to $1.757947 \mathrm{MJm}^{-3} \mathrm{c}^{-1}$ for the three depths $0.05,0.15$ and $0.30 \mathrm{~m}$ respectively.

Soil thermal conductivity increased with increasing soil moisture content. The values ranged from 1.2603 to 2.2489, 1.23222 to 2.15026 and 1.03913 to $2.18332 \mathrm{Jm}^{-1} \mathrm{~s}^{-1} \mathrm{c}^{-1}$, at moisture content ranged from 0.024 to $0.133,0.010$ to 0.103 and 0.009 to $0.122 \mathrm{~m}^{3} \mathrm{~m}^{-3}$ for the abovementioned depths, respectively. However, soil temperature showed a small effect on increasing the thermal conductivity.

Soil thermal diffusivity was affected by soil temperature and soil volumetric moisture content. They ranged from 9.22592E-07 to 13.3223E-07, from 9.10083E-07 to 14.0327E-07 and from $8.1068 \mathrm{E}-07$ to $15.1938 \mathrm{E}-07 \mathrm{~m}^{2} \mathrm{~s}^{-1}$ at three depths of $0.05,0.15$ and $0.30 \mathrm{~m}$ respectively.

Keyword: Soil volumetric heat capacity, Thermal conductivity, Thermal diffusivity.

\section{INTRODUCTION}

Thermal conductivity of a soil is a function of the thermal properties of the solid materials, soil texture, pore size distribution, water content, and the temperature of the medium. Heat flow occurs by conduction through the solid particles, through the water present as continuous films on the particles, and through the air in the soil pores. Heat transfer in moist soil also occurs as a result of vapor diffusion. Water vapor molecules diffuse from warm regions where evaporation occurs to cold regions where condensation occurs as a result of vapor

Fayoum J. Agric. Res. \& Dev., Vol. 27, No.2, July, 2013 
El-Raies, S.A.A.; et al

pressure gradients caused by temperature differences. (Sepaskhah and Boersma 1979).

The thermal properties of a soil at any location are in a constant state of flux due to diurnal and seasonal variations. The thermal characteristics of a soil are influenced by the soil volumetric water content, the volume fraction of air and the volume fraction of the soil solids. These properties are important in every aspect of soil mechanics because they indicate how energy is partitioned in the soil profile. The effect of bulk density, moisture content, salt concentration, and organic matter on the thermal conductivity of some sieved and repacked Jordanian soils was investigated through laboratory studies. Increasing the percentage of soil organic matter decreased thermal conductivity. It was found that the sand had higher values of thermal conductivity than the clay loam for the same salt type and concentrations, (Abu-Hamdeh and Reeder 2000). Dry organic horizons have considerably lower thermal conductivity than wet organic horizons and thus function as good insulators against warm air temperature (O'Donnell, et al, 2009). Wet organic horizons also dampen the amplitude of seasonal temperature variations through the absorption and release of latent heat during phase transitions (Romanovsky and Osterkamp, 2000).

A soil profile describes how energy is dispersed through a crosssectional slice of the soil from the surface to various depths. The thermal properties, such as thermal conductivity, are related to the temperature of the soil and reflect the heat transfer throughout the soil by radiation, conduction and convection. As one would expect, the temperature variations are hottest at the surface and decrease with depth depending on the thermal characteristics of the soil. Awadalla (1977) found that specific heat values decreased from coarse to fine sand then progressively increased in the clay fraction. He attributed the high values of coarse sand fraction to its mineral composition, and added that the volumetric heat capacity increased with increasing soil moisture retention.

The presence of water has a strong influence on the soil thermal properties, including thermal conductivity and soil heat capacity. Thermal conductivity is a measure of the ease with which a soil transmits heat, in that it describes the heat flow in response to a thermal gradient. Water has a high heat capacity in that it takes less heat to raise the soil temperature in a dry soil than in a wet soil. Wet soils conduct heat better than dry soils.

Adjepong (1997) mentioned that the rate of increase of the specific heat capacity with moisture content is found to be high in the clayey soil and low in the sandy soil. He added that in the considered range $(0-25 \%)$ of moisture content, the specific heat capacities of the soil increase with moisture content. In the case of the sandy soil, the increase is found to be linear over the considered range.

Fayoum J. Agric. Res. \& Dev., Vol. 27, No.2, July, 2013 
THE EFFECT OF SOIL TEMPERATURE AND MOISTURE..........

Khalifa (1992) mentioned that the evaporation is very important when using the coupled heat and water flow equations to predict soil temperatures.

Abd El-Dayem (1999) mentioned that the values of both thermal conductivity and thermal diffusivity increased markedly with increasing soil temperature. On the other hand, values of the volumetric heat capacity were not affected with soil temperature.

Accurate estimates of soils thermal conductivity are of prime importance in the numerical simulation of heat transmission through soils. Soil thermal conductivity estimation methods that could easily be incorporated in computer algorithms will have wide application. Factors affecting soil thermal conductivity include moisture, mineral composition and temperature. Moisture content, by far, has the greatest impact upon soil thermal conductivity. As moisture is added to a soil, a thin water film develops which bridges the gaps between the soil particles. This bridging increases the effective contact area between the soil particles, which increases the heat flow and results in higher thermal conductivity. As the voids between the soil particles become completely filled with moisture, the soil thermal conductivity no longer increases with increasing moisture content, (Penner et al, 1975).

Soil thermal conductivity also varies with the mineral composition of the soil. For examples, sands with a high quartz content generally have a greater thermal conductivity than sands with high contents of plagioclase feldspar and pyroxene, (Kersten, 1949). Bora et al, (1990) found that thermal diffusivity of soil was lower near the surface compared with deeper depths.

The objective of the investigation is to calculate thermal properties of sandy soil of Ismailia Agricultural Research Station under a cover of alfalfa plants.

Theoretical consideration:

According to De Vries (1963), Kimball et al, (1976), Fritschen and Gay (1979) and Khalifa (1992)

Volumetric heat capacity $\left(C_{v}\right)\left(\mathrm{Jm}^{-3} \mathrm{c}^{-1}\right)$ according (De vries 1963):

$$
C_{v}=\sum_{i=1}^{n} C_{i} X_{i} \quad\left(J^{-3} c^{-1}\right)
$$

Where; $\begin{aligned} C_{i} & =\text { volumetric heat capacity of the } \mathrm{i}^{- \text {th }} \text { soil constituent } \\ X_{i} & =\text { volume fraction of the } \mathrm{i}^{- \text {th }} \text { soil constituent }\end{aligned}$

Soil volumetric heat capacity was calculated from the sum of the volumetric heat capacities of different components of the soil:

$$
C_{v}=1.92 X_{m}+2.51 X_{o}+4.18 X_{w}
$$

Where $C_{v}$ is the volumetric heat capacity of the soil (MJ $\mathrm{m}^{-3} \mathrm{c}^{-1}$ ); and $X_{m}, X_{o}$, and $X_{w}$ are the volume fraction of soil mineral, organic matter, and moisture content respectively.

Fayoum J. Agric. Res. \& Dev., Vol. 27, No.2, July, 2013 
El-Raies, S.A.A.; et al

Table ( 1 ):Volumetric heat capacity of soil constituents (Cv)

\begin{tabular}{|c|c|}
\hline Constituents & Volumetric Heat Capacity (Cv) \\
\hline Air (Ca) & $1256.3\left(\mathrm{Jm}^{-3} \mathrm{c}^{-1}\right)$ \\
\hline Liquid water $(\mathrm{Ci})$ & $4187600\left(\mathrm{Jm}^{-3} \mathrm{c}^{-1}\right)$ \\
\hline Silt and clay $(\mathrm{Cm}$ & $1926000\left(\mathrm{Jm}^{-3} \mathrm{c}^{-1}\right)$ \\
\hline Organic matter (Com) & $2513000\left(\mathrm{Jm}^{-3} \mathrm{c}^{-1}\right)$ \\
\hline Quartz $(\mathrm{Cq})$ & $1926000\left(\mathrm{Jm}^{-3} \mathrm{c}^{-1}\right)$ \\
\hline Gravel $(\mathrm{Cg})$ & $1926000\left(\mathrm{Jm}^{-5} \mathrm{c}^{-1}\right)$ \\
\hline
\end{tabular}

The thermal conductivity $(\lambda)\left(\mathrm{Jm}^{-1} \mathrm{~s}^{-1} \mathrm{c}^{-1}\right)$

The thermal conductivity of soil (De Vries 1963) is calculated as the weighted average of the conductivities of various soil components:

$$
\lambda=\frac{\sum_{i=1}^{n} k_{i} \lambda_{i} x_{i}}{\sum_{i=1}^{n} k_{i} x_{i}} \quad\left(\operatorname{Jm}^{-1} s^{-1} c^{-1}\right)
$$

where $\boldsymbol{n}$ - number of components, $\lambda_{i}$ is the thermal conductivity of each components, and $\boldsymbol{x}_{\boldsymbol{i}}$ is the volume fraction of each components, and $\mathrm{K}_{\mathrm{i}}$ is the ratio of the average temperature gradient, which the previous equation is detailed as follow;

$$
\lambda=\frac{K_{W} \theta \lambda_{W}+K_{a} X_{a} \lambda_{a v}+K_{q} X_{q} \lambda_{q}+K_{m} X_{m} \lambda_{m}+K_{o} X_{o} \lambda_{o}+K_{g} X_{g} \lambda_{g}}{K_{w} \theta+K_{a} X_{a}+K_{q} X_{q}+K_{m} X_{m}+K_{o} X_{o}+K_{g} X_{g}}
$$

Volumes of $k_{i}$ are calculated for air or water from

$$
\begin{gathered}
K_{i}=\left(\frac{2}{3}\right)\left[1+\left(\frac{\lambda_{i}}{\lambda_{o}}-1\right) g_{i}\right]^{-1}+\left(\frac{1}{3}\right)\left[1+\left(\frac{\lambda_{i}}{\lambda_{o}}-1\right)\left(1-2 g_{i}\right)\right]^{-1} \\
g_{i}=0.035+\left(\frac{0.298}{\varepsilon}\right) \theta \quad \theta \equiv O_{w p}{ }^{(\mathrm{A})} \\
g_{i}=0.013+\left(\frac{0.022}{\theta_{w p}}+\frac{0.298}{\varepsilon}\right) \theta \quad \theta \subset \theta_{w p}^{(\mathrm{B})}
\end{gathered}
$$

Where $g_{i}$ represents the shape factors for $i^{\text {th }}$ components granules considered as ellipsoids, $\varepsilon$ is soil porosity and $\theta_{\mathrm{wp}}$ is volumetric water content at wilting point.

Fayoum J. Agric. Res. \& Dev., Vol. 27, No.2, July, 2013 
THE EFFECT OF SOIL TEMPERATURE AND MOISTURE..........

Table ( 2 ): Thermal conductivity $\lambda$, ratio of the average temperature gradient through soil granules (Ki) and shape factor of the constituents (except air)

\begin{tabular}{|l|l|l|l|}
\hline Constituents & \multicolumn{1}{|c|}{$\boldsymbol{\lambda}\left(\mathbf{J m}^{-1} \mathbf{s}^{-1} \mathbf{c}^{-\mathbf{1}}\right)$} & $\mathbf{K i}$ & $\mathbf{g}_{\mathbf{i}}$ \\
\hline Air $(\lambda \mathrm{av})$ & $0.02513+\lambda \mathrm{v}_{\mathrm{v}}$ & 1 & Calculate \\
\hline Water $(\lambda \mathrm{w})$ & 0.5737 & 1 & $\ldots \ldots$ \\
\hline Silt + clay $(\lambda \mathrm{m})$ & 2.931 & 0.5223 & 0.125 \\
\hline Organic matter $(\lambda \mathrm{om})$ & 0.2513 & 1.2608 & 0.5 \\
\hline Quartz $(\lambda \mathrm{q})$ & 8.794 & 0.2674 & 0.125 \\
\hline Gravel $(\lambda \mathrm{g})$ & 6.3389 & 0.50395 & 0.144 \\
\hline
\end{tabular}

Table ( 3 ) Atmospheric information

\begin{tabular}{|l|l|l|}
\hline Parameter & Description & Values \\
\hline Po & Atmospheric pressure at sea level & $101325 \mathrm{~Pa}$ \\
\hline Tlr & Temperature lapse rate & $0.0065 \mathrm{Km}^{-1}$ \\
\hline To & Temperature at sea level & $288.15 \mathrm{~K}$ \\
\hline g & Acceleration due to gravity & $9.80665 \mathrm{~ms}^{-2}$ \\
\hline $\mathrm{M}$ & Molar mass of dry air & $0.0289644 \mathrm{~kg} \mathrm{~mol}^{-1}$ \\
\hline $\mathrm{R}$ & Gas constant of water vapor & $8.3144 \mathrm{~J} \mathrm{~mol}^{-1} \mathrm{~K}^{-1}$ \\
\hline $\mathrm{Mw}$ & Molecular weight of water vapor & $0.018016 \mathrm{~kg} \mathrm{~mol}^{-1}$ \\
\hline $\mathrm{Z}$ & Elevation for Ismailia & $10.2 \mathrm{~m}$ \\
\hline
\end{tabular}

Table (2) showed thermal conductivity of every constituents except for air-filled pores is composed of a part due to normal heat conduction $\lambda_{\mathrm{a}}$, and a part due to vapor movement $\lambda_{\mathrm{v}}$, it should be calculated the conductivity of water vapor which can be given as described by De Vries 1963, and table (3) showed some atmospheric information.

$$
\begin{gathered}
\lambda a v=\lambda a+\lambda v \\
\lambda_{v}=h L D_{a t m} V \beta
\end{gathered}
$$

Where $\mathrm{h}$ is the relative humidity of the air filled pores, $\mathrm{L}$ is the latent heat of vaporization of water, $\mathrm{D}_{\mathrm{atm}}$ is the molecular diffusion coefficient of water vapor into air, $\mathrm{V}$ is the mass flow factor and $\beta$ is the derivative of the saturated vapor density with respect to temperature, (Khalifa, 1992).

$$
\begin{aligned}
& h=\exp \left(\frac{\psi g M_{w}}{R\left(T_{s}+273.16\right)}\right) \\
& L=3.149(10)^{6}-2.37(10)^{3}\left(T_{s}+273.16\right) \\
& D_{a t m}=2.29 \times 10^{-5}\left(\frac{T_{s}+273.16}{273.16}\right)^{1.75}
\end{aligned}
$$

Fayoum J. Agric. Res. \& Dev., Vol. 27, No.2, July, 2013 


$$
\begin{aligned}
& P_{\text {sat }}=10^{3} \exp \left(6.0035-\frac{4975.9}{T_{s}+273.16}\right) \\
& P=P_{O} \times\left(1-\frac{\operatorname{Tlr} \times Z}{\operatorname{TO}}\right)^{\frac{g \times M}{R \times T l r}} \\
& V=\frac{P}{\left(P-\left(\frac{h P_{s a t} R\left(T_{s}+273.16\right)}{M_{w}}\right)\right)} \\
& \beta=P_{\text {sat }}\left(\frac{4975.9}{\left(T_{s}+273.16\right)^{2}}\right)
\end{aligned}
$$

Where g, M, R, Tlr, Z and To are shown in table (4), Mw is molecular weight of water vapor $\left(=0.018016 \mathrm{~kg} \mathrm{~mol}^{-1}\right)$, Psat is saturated vapor density $\left(\mathrm{kg} \mathrm{m}^{-3}\right)$ and $\mathrm{P}$ is atmospheric pressure $(\mathrm{Pa})$

$$
\Psi=-\exp \left(\begin{array}{l}
61.66-1832.126 \times \theta+22524.45 \times \theta^{2}-140527.6 \times \theta^{3} \\
+466504.8 \times \theta^{4}-784028 \times \theta^{5}+522315 \times \theta^{6}
\end{array}\right)
$$

Thermal diffusivity $\left(\alpha \underline{\left(\mathrm{m}^{2} \mathrm{~s}^{-1}\right) \text { : }}\right.$

$$
\begin{aligned}
\alpha & \frac{\lambda}{\alpha v} \\
C_{v}=\text { Volumetric heat capacity } & \left(\mathrm{Jm}^{-3} \mathrm{c}^{-1}\right) \\
\lambda=\text { Thermal conductivity } & \left(\mathrm{Jm}^{-1} \mathrm{~s}^{-1} \mathrm{c}^{-1}\right) \\
\alpha=\text { Thermal diffusivity } & \left(\mathrm{m}^{2} \mathrm{~s}^{-1}\right)
\end{aligned}
$$

\section{MATERIALS AND METHODS}

Fifty one registers (one every week) of soil temperatures in 51 weeks through twelve months from January to December were recorded for every depth. They were recorded for three soil depths $(0.05,0.15$, and $0.30 \mathrm{~m}$ ) in a sandy soil that covered with alfalfa plants in Ismailia Agriculture Research Station of Ismailia governorate. Quarter-hour mean temperatures were recorded at data logger with type-T thermocouple probes for the three soil depths. The total registers recorded were (51 observations $x \quad 3$ depths) 153 observations. One hundred and fifty three soil samples were collected from the same locations of the three depths in the same 51 weeks to determine the soil moisture content. Soil heat properties as volumetric heat capacity (VHC or $\boldsymbol{C V}$ ) (Volumetric heat capacity of the constituents (Cv) Table 1), thermal conductivity (Thc or $\lambda$ ) (thermal conductivity $(\lambda)$, ratio of the average temperature gradient through soil granules (Ki) and shape factor of the constituents (except air) Table 2), (atmospheric information

Fayoum J. Agric. Res. \& Dev., Vol. 27, No.2, July, 2013 
THE EFFECT OF SOIL TEMPERATURE AND MOISTURE......... 7 Table 3) and thermal diffusivity ( $\boldsymbol{X}$ ) were estimated according to Khalifa (1992), Arshad and Azooz (1996), Don scott (2000), De Vries (1963) and Kimball et al (1976). Soil properties of the initial soil surface samples $(0-30 \mathrm{~cm})$ (Table 4$)$ and soil moisture contents for all collected soil samples were determined after Piper (1950), Page et al, (1982) and Klute (1986).

Table ( 4 ): Some soil properties of the studied soil

\begin{tabular}{|l|c|l|l|l|c||}
\hline \multicolumn{2}{|l|}{ Soil properties } & \multicolumn{2}{l|}{ Volumetric fraction } & \multicolumn{2}{l||}{ Soil properties } \\
\hline \hline C.sand (\%) & 63.80 & Sand & 0.55483 & $\mathrm{BD}\left(\mathrm{gm}^{-3}\right)$ & 1.69 \\
\hline F.sand (\%) & 23.20 & Silt+clay & 0.08291 & Porosity $(\%)$ & 39.52 \\
\hline Silt (\%) & 5.50 & OM & 0.00676 & FC $(\%)$ & 7.90 \\
\hline Clay (\%) & 7.50 & & & WP $(\%)$ & 1.42 \\
\hline O.M (\%) & 0.52 & & & AW $(\%)$ & 6.48 \\
\hline $\mathrm{CaCO}_{3}(\%)$ & 2.55 & & & EC $\left(\mathrm{dSm}^{-1}\right)$ & 0.25 \\
\hline
\end{tabular}

RESULTS AND DISCUSSION

1.Volumetric heat capacity:

Effect of volumetric soil moisture content on volumetric heat capacity:

The results revealed that volumetric heat capacity and volumetric moisture content for soil depths of $0-0.05,0.05-0.15$ and $0.15-0.30 \mathrm{~m}$ through twelve months were more closely related to each other, and take the similar trend.

Data listed in Table (5) revealed the values of ranked ascending soil moisture percent and their effect on volumetric heat capacity, They represented the average matched of every 6 to 8 times moisture content verses the average of volumetric heat capacity for every depth. The values of volumetric heat capacity increased with increasing moisture content. These can be explained that the components of any soil type either of clay, silt, sand or more or less for little of organic matter are constant, but moisture content are changed whatever with period and type of irrigation, percolation, evapotranspiration, cultivated crop, stage of growth or climatic conditions.

Table (5): Volumetric heat capacity $\left(\mathrm{MJm}^{-3} \mathrm{c}^{-1}\right)$ versus ranked ascending the soil moisture percent $(\%)$

\begin{tabular}{|c|c|c|c|c|c||}
\hline \multicolumn{2}{|c|}{$\mathbf{0 - 0 . 0 5 m}$} & \multicolumn{2}{c|}{$\mathbf{0 . 0 5 - 0 . 1 5 m}$} & \multicolumn{2}{c||}{$\mathbf{0 . 1 5 - 0 . 3 0 m}$} \\
\hline $\begin{array}{c}\text { Soil } \\
\text { moist.\% }\end{array}$ & $\begin{array}{c}\mathbf{C V} \\
\left(\mathbf{M J m}^{-3} \mathbf{c}^{-\mathbf{1}}\right)\end{array}$ & $\begin{array}{c}\text { Soil moist. } \\
\text { \% }\end{array}$ & $\begin{array}{c}\mathbf{C V} \\
\left(\mathbf{M J m}^{-3} \mathbf{c}^{-\mathbf{1}}\right)\end{array}$ & $\begin{array}{c}\text { Soil moist. } \\
\mathbf{\%}\end{array}$ & $\begin{array}{c}\mathbf{C V} \\
\left(\mathbf{M J} / \mathbf{m}^{-3} \mathbf{c}^{-\mathbf{1}}\right)\end{array}$ \\
\hline \hline 1 & 1.4870 & 1 & 1.5205 & 1 & 1.5160 \\
\hline 2 & 1.5376 & 2 & 1.4985 & 2 & 1.4902 \\
\hline 3 & 1.4979 & 3 & 1.4899 & 3 & 1.5010 \\
\hline 4 & 1.5300 & 4 & 1.5228 & 4 & 1.5281 \\
\hline 5 & 1.5954 & 5 & 1.5990 & 5 & 1.5924 \\
\hline 6 & 1.6609 & 6 & 1.6702 & 6 & 1.6634 \\
\hline 7 & 1.7250 & & & 7 & 1.7579 \\
\hline 8 & 1.7978 & & & & \\
\hline
\end{tabular}

Fayoum J. Agric. Res. \& Dev., Vol. 27, No.2, July, 2013 
El-Raies, S.A.A.; et al

The values in table (6) showed minimum, maximum and average of soil volumetric heat capacity and soil volumetric moisture content. Whereas, volumetric heat capacity ranged from 1.345479 to $1.803934,1.286049$ to 1.678707 and 1.281804 to $1.757947 \mathrm{MJm}^{-3} \mathrm{c}^{-1}$ for the three successive soil depths respectively.

Table (6). Effect of volumetric soil moisture $\left(\mathrm{m}^{3} \mathrm{~m}^{-3}\right)$ on volumetric heat capacity $\left(\mathrm{MJm}^{-3} \mathrm{c}^{-1}\right)$ at the three depths.

\begin{tabular}{|c|c|c|c|c|c|c|}
\hline \multirow{3}{*}{$\begin{array}{l}\text { Parame } \\
\text {-ter }\end{array}$} & \multicolumn{2}{|c|}{ 0-0.05m } & \multicolumn{2}{|c|}{ 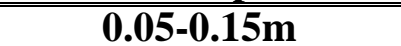 } & \multicolumn{2}{|c|}{ 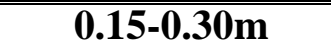 } \\
\hline & $\begin{array}{c}\text { Soil } \\
\text { moist. }\end{array}$ & $\mathrm{CV}$ & Soil moist. & $\mathrm{CV}$ & $\begin{array}{c}\text { Soil } \\
\text { moist. }\end{array}$ & CV \\
\hline & $\mathrm{m}^{3} \mathrm{~m}^{-3}$ & $\mathrm{MJm}^{-3} \mathrm{c}^{-\mathrm{I}}$ & $m^{3} m^{-5}$ & $\mathrm{MJm}^{-3} \mathrm{c}^{-\mathrm{I}}$ & $M^{3} m^{-3}$ & $\mathrm{MJm}^{-3} \mathrm{c}^{-\mathrm{T}}$ \\
\hline Min & 0.0238 & 1.345479 & 0.0096 & 1.286049 & 0.0086 & 1.281804 \\
\hline Max & 0.1333 & 1.803934 & 0.1034 & 1.678707 & 0.1224 & 1.757947 \\
\hline Average & 0.0768 & 1.567395 & 0.0588 & 1.492249 & 0.0523 & 1.464511 \\
\hline
\end{tabular}

Fig.(1) including the curves of $\mathrm{A}, \mathrm{B}$ and $\mathrm{C}$ concern the three depths explained the role of moisture content on the thermal conductivity and the conformity between each other. Fig. (2) revealed that the volumetric heat capacity of the nearest soil surface depth $(0.05 \mathrm{~m})$ was higher than those of the other depths until the day of year (DOY) 167, then it behaved as the volumetric heat capacity of the other depths. This trend may be due to climatic conditions or moisture content which was higher at these periods for lowest depth and less for deepest ones. Adjepoug (1997) stated that the differences in the rates of increase of specific heat capacity observed for the soil can be attributed to differences in the soil water retention capacity.

Fayoum J. Agric. Res. \& Dev., Vol. 27, No.2, July, 2013 
THE EFFECT OF SOIL TEMPERATURE AND MOISTURE.......... 9

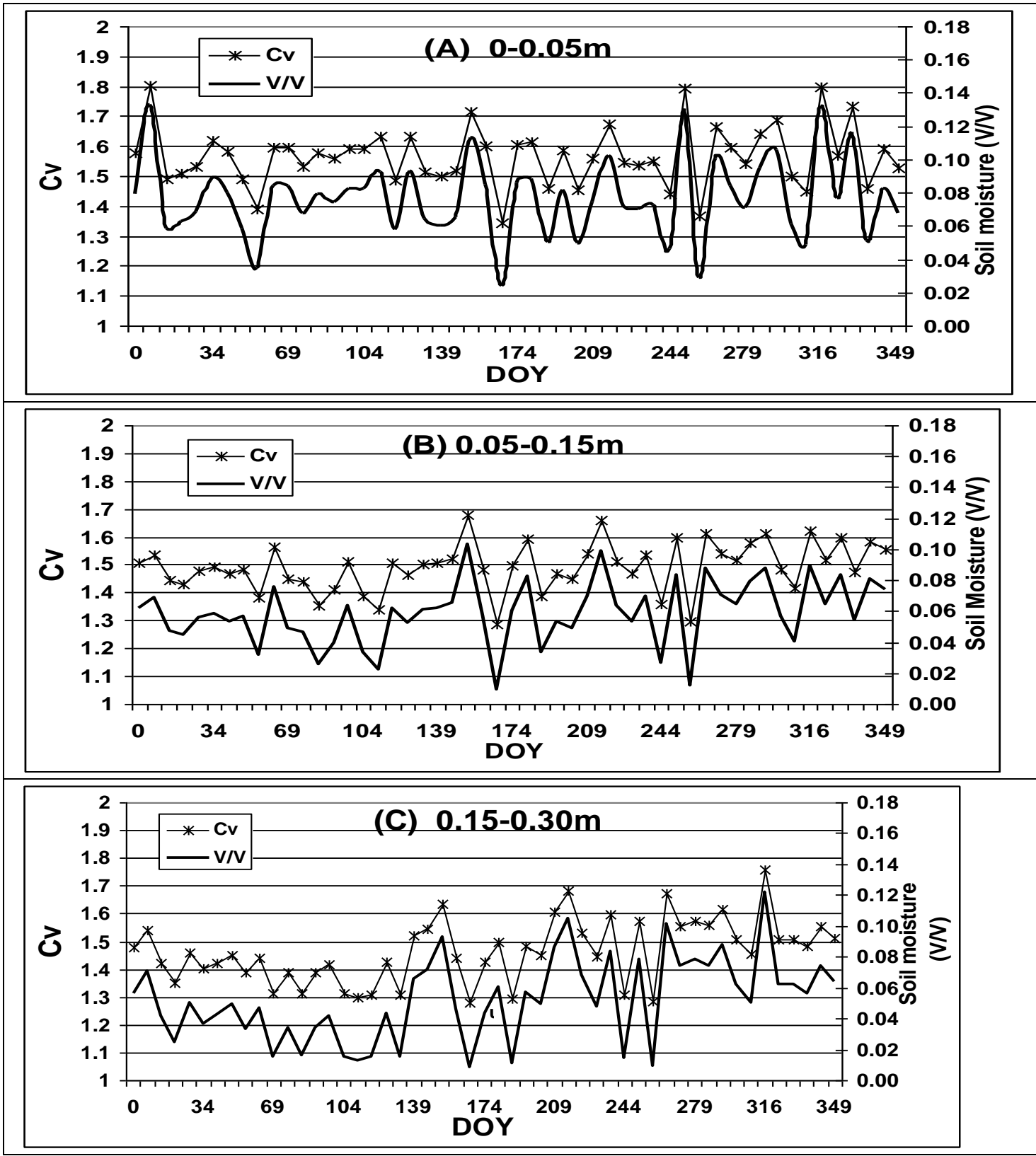

Fig.(1):Soil volumetric heat capacity $(\mathrm{CV})\left(\mathrm{MJm}^{-3} \mathrm{c}^{-1}\right)$ and volumetric moisture content $(\mathrm{v} / \mathrm{v})\left(\mathrm{m}^{3} \mathrm{~m}^{-3}\right)$ of the three soil depths (A,B and C), (DOY=Day of Year).

Fayoum J. Agric. Res. \& Dev., Vol. 27, No.2, July, 2013 


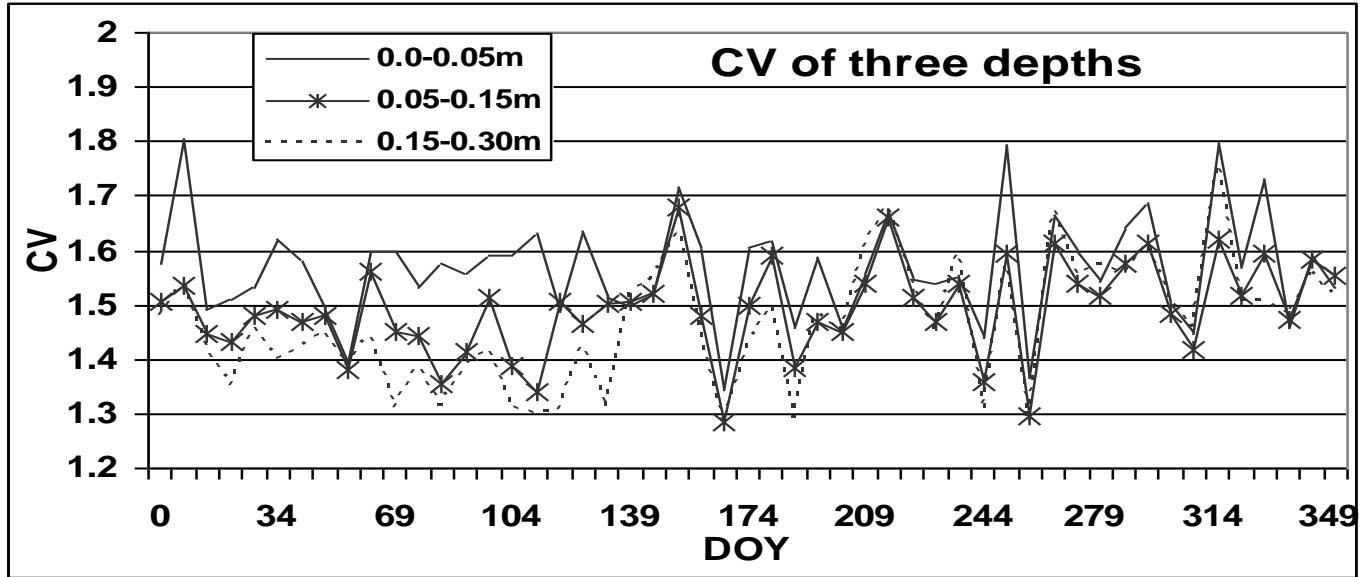

Fig. (2): Soil volumetric heat capacity $\left(\mathrm{MJm}^{-3} \mathrm{c}^{-1}\right)$ for three depths at 51 observations, (DOY = Day Of Year).

Regression equation coefficients between soil volumetric heat capacity and volumetric soil moisture content for the three depths were highly positive significant, as well as correlation coefficients were also highly positive significant, (Table 7), which confirmed the abovemention behaved.

Table (7): Regression equation and correlation coefficient of volumetric heat capacity $\left(\mathrm{MJm}^{-3} \mathrm{c}^{-1}\right)$ with soil volumetric moisture content $\left(\mathrm{m}^{3} \mathrm{~m}^{-3}\right)$.

\begin{tabular}{|c|c|c|c|c|}
\hline \multicolumn{3}{|c|}{ Regression equations } & \multirow{2}{*}{$\begin{array}{c}\text { Correlation ( } \\
\mathbf{r}) \\
\mathbf{V} / \mathbf{V}\end{array}$} & \multirow[b]{2}{*}{$\mathbf{N}$} \\
\hline $\mathbf{Y}$ & $a+b_{1} x_{1}$ & $\mathbf{R - S q}$ & & \\
\hline Cv 0.05m) & $1.24+4.28 \mathrm{~V} / \mathrm{V}$ & $97.8 * *$ & $0.989 * *$ & 51 \\
\hline $\mathrm{Cv}(0.15 \mathrm{~m})$ & $1.24+4.26 \mathrm{~V} / \mathrm{V}$ & $93.8 * *$ & $0.968 * *$ & 51 \\
\hline $\mathrm{Cv}(0.30 \mathrm{~m})$ & $1.23+4.36 \mathrm{~V} / \mathrm{V}$ & $94.6^{* * *}$ & $0.973 * *$ & 51 \\
\hline
\end{tabular}

\section{Thermal conductivity:}

Thermal conductivity is an intrinsic property of the soil (or any other substance) that is related to its ability to conduct heat. It may be called "heat flux" or "heat transfer" in that it is related to the movement of heat energy through the soil. The heat moves from an area of high temperature to a cooler area as the heat redistributes itself to reach equilibrium where the heat is evenly distributed through the substance. The increase in the thermal conductivity for added unit of water was different with different temperature, and the rate of increasing was the highest at low water content. This increase is due to the formation of wedges at the points where particles make contact. O'Donnell $\boldsymbol{e t}$ al. (2009) indicate that a strong positive and linear relationship between the thermal conductivity and volumetric water content of soil.

Table (8, 9 and 10) showed the values of soil moisture content determined versus to the moment of soil temperature through depths of $0-0.05,0.05-0.15$ and $0.15-0.30 \mathrm{~m}$. Also, they showed the shape factor

Fayoum J. Agric. Res. \& Dev., Vol. 27, No.2, July, 2013 
THE EFFECT OF SOIL TEMPERATURE AND MOISTURE......... 11 $\left(\mathrm{g}_{\mathrm{i}}\right)$ which was used in the estimation when the moisture contents were more than wilting point (A), and when the moisture contents were less than wilting point (B).

Table (8): Soil moisture content $(\%)$ verses the soil temperature $\left({ }^{\circ} \mathrm{C}\right)$ and shape factor $\left(\mathrm{g}_{\mathrm{i}}\right)$ for the depth of $0-0.05 \mathrm{~m}$ (DOY=Day Of Year).

\begin{tabular}{|c|c|c|c|c|c|c|c|c|c|c|c|}
\hline \multirow[b]{2}{*}{ DOY } & \multicolumn{3}{|c|}{ 0-0.05m } & \multirow[b]{2}{*}{ DOY } & \multicolumn{3}{|c|}{$0-0.05 m$} & \multirow[b]{2}{*}{ DOY } & \multicolumn{3}{|c|}{$\overline{0-0.05 m}$} \\
\hline & $\mathbf{T}\left({ }^{\circ} \mathbf{C}\right)$ & $\begin{array}{c}\text { Soil } \\
\text { moist. \% }\end{array}$ & $\mathbf{g}_{\mathbf{i}}$ & & $\mathbf{T}\left({ }^{\circ} \mathrm{C}\right)$ & $\begin{array}{c}\text { Soil } \\
\text { moist. \% }\end{array}$ & $\mathbf{g}_{\mathbf{i}}$ & & $\mathbf{T}\left({ }^{\circ} \mathbf{C}\right)$ & $\begin{array}{c}\text { Soil } \\
\text { moist. \% }\end{array}$ & $\mathbf{g}_{\mathbf{i}}$ \\
\hline 0 & 12.62 & 4.67 & $\mathrm{~A}$ & 118 & 17.90 & 3.41 & $\overline{\mathrm{A}}$ & 237 & 24.72 & 44.32 & $\overline{\mathrm{A}}$ \\
\hline 6 & 13.30 & 7.89 & $\mathrm{~A}$ & 125 & 19.06 & 5.50 & $\mathrm{~A}$ & 244 & 25.25 & 2.74 & $\mathrm{~A}$ \\
\hline 13 & 12.05 & 3.46 & $\mathrm{~A}$ & 132 & 26.24 & 3.80 & $\mathrm{~A}$ & 251 & 24.74 & 7.72 & $\mathrm{~A}$ \\
\hline 20 & 11.55 & 3.72 & A & 139 & 24.49 & 3.58 & A & 258 & 24.55 & 1.70 & A \\
\hline 27 & 11.67 & 4.06 & A & 146 & 25.57 & 3.86 & $\mathrm{~A}$ & 265 & 25.07 & 5.94 & A \\
\hline 34 & 10.46 & 5.27 & $\mathrm{~A}$ & 153 & 24.61 & 6.67 & $\bar{A}$ & 272 & 21.26 & 4.98 & $\bar{A}$ \\
\hline 41 & 10.53 & 4.74 & $\mathrm{~A}$ & 160 & 30.30 & 5.02 & $\mathrm{~A}$ & 279 & 22.63 & 4.18 & $\overline{\mathrm{A}}$ \\
\hline 48 & 11.58 & 3.49 & $\mathrm{~A}$ & 167 & 27.27 & 1.41 & $\mathrm{~B}$ & 286 & 22.86 & 5.62 & A \\
\hline 55 & 10.95 & 2.07 & $\mathrm{~A}$ & 174 & 25.15 & 5.10 & $\mathrm{~A}$ & 293 & 19.56 & 6.24 & A \\
\hline 62 & 13.34 & 4.96 & $\bar{A}$ & 181 & 28.98 & 5.23 & $\bar{A}$ & 300 & 20.42 & 3.62 & $\mathrm{~A}$ \\
\hline 69 & 12.08 & 4.96 & A & 188 & 27.57 & 3.00 & $\mathrm{~A}$ & 307 & 18.58 & 2.87 & $\mathrm{~A}$ \\
\hline 76 & 13.27 & 4.02 & A & 195 & 27.44 & 4.85 & A & 314 & 17.06 & 7.80 & A \\
\hline 83 & 13.08 & 4.67 & $\bar{A}$ & 202 & 26.49 & 2.93 & $\overline{\mathrm{A}}$ & 321 & 16.06 & 4.54 & $\mathrm{~A}$ \\
\hline 90 & 21.95 & 4.42 & $\bar{A}$ & 209 & 27.22 & 4.42 & $\overline{\mathrm{A}}$ & 328 & 16.55 & 6.88 & $\overline{\mathrm{A}}$ \\
\hline 97 & 20.54 & 4.88 & $\overline{\mathrm{A}}$ & 216 & 26.37 & 6.04 & $\overline{\mathrm{A}}$ & 335 & 14.47 & 3.31 & $\overline{\mathrm{A}}$ \\
\hline 104 & 16.44 & 4.88 & $\mathrm{~A}$ & 223 & 26.25 & 4.26 & $\mathrm{~A}$ & 342 & 12.72 & 4.88 & $\mathrm{~A}$ \\
\hline 111 & 20.46 & 5.46 & $\mathrm{~A}$ & 230 & 25.08 & 4.14 & $\mathrm{~A}$ & 349 & 11.89 & 3.99 & $\mathrm{~A}$ \\
\hline
\end{tabular}

Table (9): Soil moisture content $(\%)$ verses the soil temperature $\left({ }^{\circ} \mathrm{C}\right)$ and shape factor $\left(g_{i}\right)$ for the depth of 0.05-0.15m (DOY=Day Of Year).

\begin{tabular}{|c|c|c|c|c|c|c|c|c|c|c|c|}
\hline \multirow[b]{2}{*}{ DOY } & \multicolumn{3}{|c|}{ 0.05-0.15m } & \multirow[b]{2}{*}{ DOY } & \multicolumn{3}{|c|}{ 0.05-0.15m } & \multirow[b]{2}{*}{ DOY } & \multicolumn{3}{|c|}{ 0.05-0.15m } \\
\hline & $\begin{array}{c}\mathbf{T} \\
\left({ }^{\circ} \mathbf{C}\right)\end{array}$ & $\begin{array}{c}\text { Soil } \\
\text { moist.\% }\end{array}$ & $\mathbf{g}_{\mathbf{i}}$ & & $\begin{array}{c}\mathbf{T} \\
\left({ }^{\circ} \mathbf{C}\right) \\
\end{array}$ & $\begin{array}{c}\text { Soil } \\
\text { moist. \% }\end{array}$ & $\mathbf{g}_{\mathbf{i}}$ & & $\begin{array}{c}\mathbf{T} \\
\left({ }^{\circ} \mathbf{C}\right)\end{array}$ & $\begin{array}{c}\text { Soil moist } \\
\%\end{array}$ & $\mathbf{g}_{\mathbf{i}}$ \\
\hline 0 & 12.32 & 3.68 & $\mathrm{~A}$ & 118 & 18.08 & 3.68 & $\mathrm{~A}$ & 237 & 24.65 & 4.13 & $\mathrm{~A}$ \\
\hline 6 & 13.27 & 4.09 & $\mathrm{~A}$ & 125 & 18.43 & 3.12 & $\mathrm{~A}$ & 244 & 25.15 & 1.59 & $\mathrm{~A}$ \\
\hline 13 & 11.72 & 2.82 & $\mathrm{~A}$ & 132 & 27.12 & 3.62 & A & 251 & 25.62 & 4.95 & A \\
\hline 20 & 11.55 & 2.64 & A & 139 & 24.73 & 3.67 & A & 258 & 25.18 & 0.72 & $\mathrm{~B}$ \\
\hline 27 & 11.91 & 3.32 & $\bar{A}$ & 146 & 26.86 & 3.87 & $\bar{A}$ & 265 & 24.77 & 5.18 & $\bar{A}$ \\
\hline 34 & 10.43 & 3.49 & $\mathrm{~A}$ & 153 & 24.68 & 6.12 & $\mathrm{~A}$ & 272 & 21.15 & 4.17 & $\mathrm{~A}$ \\
\hline 41 & 10.12 & 3.18 & $\mathrm{~A}$ & 160 & 32.96 & 3.34 & A & 279 & 22.73 & 3.83 & A \\
\hline 48 & 11.83 & 3.34 & $\mathrm{~A}$ & 167 & 29.65 & 0.57 & B & 286 & 22.83 & 4.69 & $\mathrm{~A}$ \\
\hline 55 & 10.94 & 1.91 & $\mathrm{~A}$ & 174 & 25.89 & 3.57 & $\mathrm{~A}$ & 293 & 19.60 & 5.20 & $\mathrm{~A}$ \\
\hline 62 & 13.31 & 4.48 & $\mathrm{~A}$ & 181 & 28.56 & 4.90 & A & 300 & 20.38 & 3.38 & $\mathrm{~A}$ \\
\hline 69 & 11.97 & 2.88 & A & 188 & 27.52 & 1.98 & A & 307 & 18.33 & 2.42 & A \\
\hline 76 & 12.77 & 2.77 & $\mathrm{~A}$ & 195 & 28.07 & 3.17 & $\mathrm{~A}$ & 314 & 16.91 & 5.31 & $\mathrm{~A}$ \\
\hline 83 & 13.28 & 1.53 & $\mathrm{~A}$ & 202 & 26.75 & 2.89 & $\mathrm{~A}$ & 321 & 15.92 & 3.82 & $\bar{A}$ \\
\hline 90 & 21.94 & 2.36 & $\mathrm{~A}$ & 209 & 27.15 & 4.14 & $\bar{A}$ & 328 & 16.29 & 4.95 & $\mathrm{~A}$ \\
\hline 97 & 19.73 & 3.79 & $\mathrm{~A}$ & 216 & 26.10 & 5.88 & $\mathrm{~A}$ & 335 & 14.23 & 3.28 & $\mathrm{~A}$ \\
\hline 104 & 16.50 & 2.01 & $\mathrm{~A}$ & 223 & 26.90 & 3.76 & $\mathrm{~A}$ & 342 & 12.47 & 4.77 & $\mathrm{~A}$ \\
\hline 111 & 20.58 & 1.32 & B & 230 & 25.35 & 3.14 & A & 349 & 11.62 & 4.37 & A \\
\hline
\end{tabular}

Fayoum J. Agric. Res. \& Dev., Vol. 27, No.2, July, 2013 
Table(10):Soil moisture content $(\%)$ verses the soil temperature $\left({ }^{\circ} \mathrm{C}\right)$ and shape factor $\left(\mathrm{g}_{\mathrm{i}}\right)$ for the depth of $0.15-0.30 \mathrm{~m}$ (DOY=Day Of Year).

\begin{tabular}{|c|c|c|c|c|c|c|c|c|c|c|c|}
\hline \multirow[b]{2}{*}{ DOY } & \multicolumn{3}{|c|}{ 0.15-0.30m } & \multirow[b]{2}{*}{ DOY } & \multicolumn{3}{|c|}{ 0.15-0.30m } & \multirow[b]{2}{*}{ DOY } & \multicolumn{3}{|c|}{ 0.15-0.30m } \\
\hline & $\begin{array}{c}\mathbf{T} \\
\left({ }^{\circ} \mathbf{C}\right)\end{array}$ & $\begin{array}{c}\text { Soil } \\
\text { moist.\% }\end{array}$ & $\mathbf{g}_{\mathbf{i}}$ & & $\begin{array}{c}\mathbf{T} \\
\left({ }^{\circ} \mathbf{C}\right)\end{array}$ & $\begin{array}{c}\text { Soil } \\
\text { moist. \% }\end{array}$ & & & $\begin{array}{c}\mathbf{T} \\
\left({ }^{\circ} \mathbf{C}\right)\end{array}$ & $\begin{array}{c}\text { Soil } \\
\text { moist.\% }\end{array}$ & $\mathbf{g}_{\mathbf{i}}$ \\
\hline 0 & 12.09 & 3.32 & A & 118 & 17.85 & 0.89 & B & 237 & 25.87 & 4.94 & $\mathrm{~A}$ \\
\hline 6 & 13.40 & 4.17 & A & 125 & 18.84 & 2.55 & A & 244 & 26.25 & 0.85 & B \\
\hline 13 & 13.25 & 2.46 & $\mathrm{~A}$ & 132 & 23.19 & 0.90 & B & 251 & 26.00 & 4.64 & $\mathrm{~A}$ \\
\hline 20 & 12.18 & 1.47 & $\bar{A}$ & 139 & 22.87 & 3.90 & $\bar{A}$ & 258 & 25.75 & 0.56 & B \\
\hline 27 & 12.42 & 3.00 & $\bar{A}$ & 146 & 23.74 & 4.23 & $\overline{\mathrm{A}}$ & 265 & 25.46 & 6.02 & $\mathrm{~A}$ \\
\hline 34 & 11.72 & 2.19 & $\mathrm{~A}$ & 153 & 22.47 & 5.50 & $\mathrm{~A}$ & 272 & 22.64 & 4.37 & $\mathrm{~A}$ \\
\hline 41 & 10.40 & 2.50 & A & 160 & 26.15 & 2.75 & A & 279 & 23.30 & 4.62 & A \\
\hline 48 & 13.30 & 2.92 & $\bar{A}$ & 167 & 25.39 & 0.51 & $\mathrm{~B}$ & 286 & 23.40 & 4.40 & $\mathrm{~A}$ \\
\hline 55 & 12.01 & 1.99 & $\mathrm{~A}$ & 174 & 25.64 & 2.56 & $\mathrm{~A}$ & 293 & 21.13 & 5.21 & $\bar{A}$ \\
\hline 62 & 13.85 & 2.79 & $\bar{A}$ & 181 & 27.16 & 3.56 & $\mathrm{~A}$ & 300 & 21.37 & 3.69 & $\bar{A}$ \\
\hline 69 & 13.01 & 0.92 & $\mathrm{~B}$ & 188 & 27.58 & 0.66 & B & 307 & 20.19 & 2.98 & $\bar{A}$ \\
\hline 76 & 13.74 & 2.02 & $\bar{A}$ & 195 & 27.40 & 3.38 & $\mathrm{~A}$ & 314 & 18.59 & 7.24 & $\mathrm{~A}$ \\
\hline 83 & 14.20 & 0.97 & B & 202 & 27.22 & 2.91 & A & 321 & 17.71 & 3.68 & A \\
\hline 90 & 18.66 & 2.02 & $\bar{A}$ & 209 & 27.54 & 5.09 & $\mathrm{~A}$ & 328 & 17.02 & 3.70 & $\bar{A}$ \\
\hline 97 & 16.26 & 2.45 & $\bar{A}$ & 216 & 26.95 & 6.19 & $\mathrm{~A}$ & 335 & 15.42 & 3.34 & $\bar{A}$ \\
\hline 104 & 17.33 & 0.92 & B & 223 & 27.58 & 4.02 & $\overline{\mathrm{A}}$ & 342 & 14.26 & 4.39 & $\mathrm{~A}$ \\
\hline 111 & 19.24 & 0.75 & B & 230 & 26.22 & 2.85 & $\mathrm{~A}$ & 349 & 13.65 & 3.78 & $\mathrm{~A}$ \\
\hline
\end{tabular}

Soil moisture content increased thermal conductivity, and the estimated values showed that thermal conductivity ranged from 1.2603 to $2.2489,1.23222$ to 2.15026 and 1.03913 to $2.18332 \mathrm{Jm}^{-1} \mathrm{~s}^{-1} \mathrm{c}^{-1}$, at moisture content ranged from 0.024 to $0.133,0.010$ to 0.103 and 0.009 to $0.122 \mathrm{~m}^{3} \mathrm{~m}^{-3}$, for the three successive soil depths, respectively (Table 11). Penner et al, (1975) reported that moisture content, by far, has the greatest impact upon soil thermal conductivity. As moisture is added to a soil, a thin water film develops which bridges the gaps between the soil particles. This bridging increases the effective contact area between the soil particles, which increases the heat flow and results in higher thermal conductivity. As the voids between the soil particles become completely filled with moisture, the soil thermal conductivity no longer increases with increasing moisture content.

Otherwise, soil temperature showed a relatively little effect on thermal conductivity, while the same above range of thermal conductivity had happened at wide range of soil temperature which they were from 10 to $30^{\circ} \mathrm{C}$ for the above three depths for all studied days of year (DOY).

Table (12) showed regression equations with highly positive significant coefficients $\left(\mathrm{P}^{* *}\right)(\mathrm{n}=51)$ between thermal conductivity $\left(\mathrm{Jm}^{-1} \mathrm{~s}^{-1} \mathrm{c}^{-1}\right)$ with soil volumetric moisture content $\left(\mathrm{m}^{3} \mathrm{~m}^{-3}\right)$ and soil temperature $(\mathrm{C})$. They confirmed the relation between thermal conductivity with temperature and volumetrically moisture content. Also, correlation coefficients were highly positive significant.

Fayoum J. Agric. Res. \& Dev., Vol. 27, No.2, July, 2013 
THE EFFECT OF SOIL TEMPERATURE AND MOISTURE.

Whereas, correlation coefficients of thermal conductivity for the three depths with volumetric moisture content were higher than those with soil temperature which confirmed the important role of moisture that superior the temperature.

Table (11). Effect of volumetric soil moisture content $\left(\mathrm{m}^{3} \mathrm{~m}^{-3}\right)$ on soil thermal conductivity $\left(\mathrm{Jm}^{-1} \mathrm{~s}^{-1} \mathrm{c}^{-1}\right)$ at the three depths.

\begin{tabular}{|c|c|c|c|c|c|c|}
\hline \multirow{3}{*}{ Parameter } & \multicolumn{2}{|c|}{ 0-0.05m } & \multicolumn{2}{|c|}{$0.05-0.15 \mathrm{~m}$} & \multicolumn{2}{|c|}{$0.15-0.30 \mathrm{~m}$} \\
\hline & $\begin{array}{c}\text { Soil } \\
\text { moist. }\end{array}$ & $\pi$ & $\begin{array}{c}\text { Soil } \\
\text { moist. }\end{array}$ & ג & $\begin{array}{c}\text { Soil } \\
\text { moist }\end{array}$ & $\lambda$ \\
\hline & $\mathbf{m}^{5} \mathbf{m}^{-5}$ & $\mathbf{J m}^{-1} \mathbf{s}^{-1} \mathbf{c}^{-1}$ & $\mathbf{M}^{3} \mathbf{m}^{-5}$ & $\mathbf{J m}^{-1} \mathbf{s}^{-1} \mathbf{c}^{-1}$ & $m^{3} m^{-3}$ & $\mathbf{J m}^{-1} \mathbf{s}^{-1} \mathbf{c}^{-1}$ \\
\hline Min. & 0.024 & 1.2603 & 0.010 & 1.23222 & 0.009 & 1.03913 \\
\hline $\mathrm{Ma}$ & & 2.2489 & 0.103 & 2.15026 & 0.122 & 2.18332 \\
\hline Average & 0.077 & 1.8950 & 0.058 & 1.74040 & 0.051 & 1.69650 \\
\hline
\end{tabular}

Table (12): Regression equations and correlation coefficient of thermal conductivity $\left(\mathrm{Jm}^{-1} \mathrm{~s}^{-1} \mathrm{c}^{-1}\right)$ with soil volumetric moisture content $\left(\mathrm{m}^{3} \mathrm{~m}^{-3}\right)$ and soil temperature $\left({ }^{\circ} \mathrm{C}\right)$

\begin{tabular}{|c|c|c|c|c|}
\hline \multicolumn{2}{|l|}{ Regression equations } & \multicolumn{2}{|c|}{ Correlation ( $\mathbf{r}$ ) } & \multirow[b]{2}{*}{$\mathbf{N}$} \\
\hline$Y=a+b_{1} x_{1}+b_{2} x_{2}$ & R-Sq & $\mathbf{T}\left({ }^{\circ} \mathbf{C}\right)$ & $\mathbf{V} / \mathbf{V}$ & \\
\hline The $(0.05 \mathrm{~m})=1.08+0.00965 \mathrm{~T}+8.28 \mathrm{~V} / \mathrm{V}$ & $73.8 \% * *$ & $0.197 n s$ & $0.823 * *$ & 51 \\
\hline The $(0.15 \mathrm{~m})=0.892+0.0144 \mathrm{~T}+9.63 \mathrm{~V} / \mathrm{V}$ & $70.5 \% * *$ & $0.367 * *$ & $0.77 * *$ & 51 \\
\hline The $(0.30 \mathrm{~m})=0.914+0.0214 \mathrm{~T}+6.88 \mathrm{~V} / \mathrm{V}$ & $\mathbf{5 7 . 8 \% * *}$ & $0.516 * *$ & $0.668 * *$ & 51 \\
\hline
\end{tabular}

The previous results were depicted in Fig (3) which showed that soil thermal conductivity was affected by soil temperature as well as the soil moisture $\left(\mathrm{m}^{3} \mathrm{~m}^{-3}\right)$. The figures explain that soil temperature had little symmetrical effect on soil thermal conductivity, while soil moisture content had manifested harmony effect on soil thermal conductivity at the three depths. The same trend was observed from Fig (4) through twelve months from January to December.

Fayoum J. Agric. Res. \& Dev., Vol. 27, No.2, July, 2013 

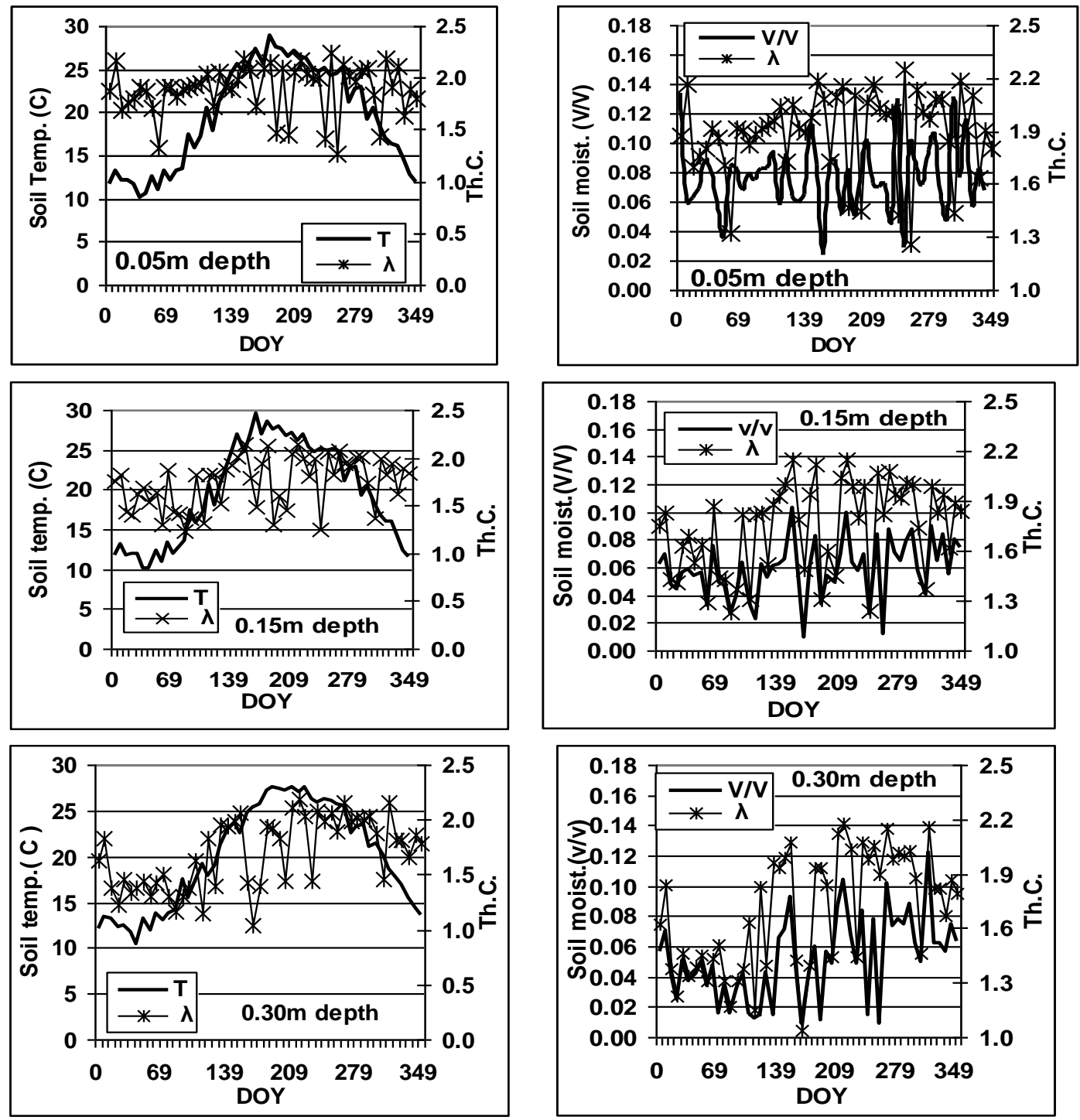

Fig. (3): Thermal conductivity (Th.C.) affected by soil temperature $\left({ }^{\circ} \mathrm{C}\right)$ and soil moisture content $\left(\mathrm{m}^{3} / \mathrm{m}^{3}\right)$ through 51 observations at three depths (DOY=Day Of Year).

Fayoum J. Agric. Res. \& Dev., Vol. 27, No.2, July, 2013 
THE EFFECT OF SOIL TEMPERATURE AND MOISTURE..........
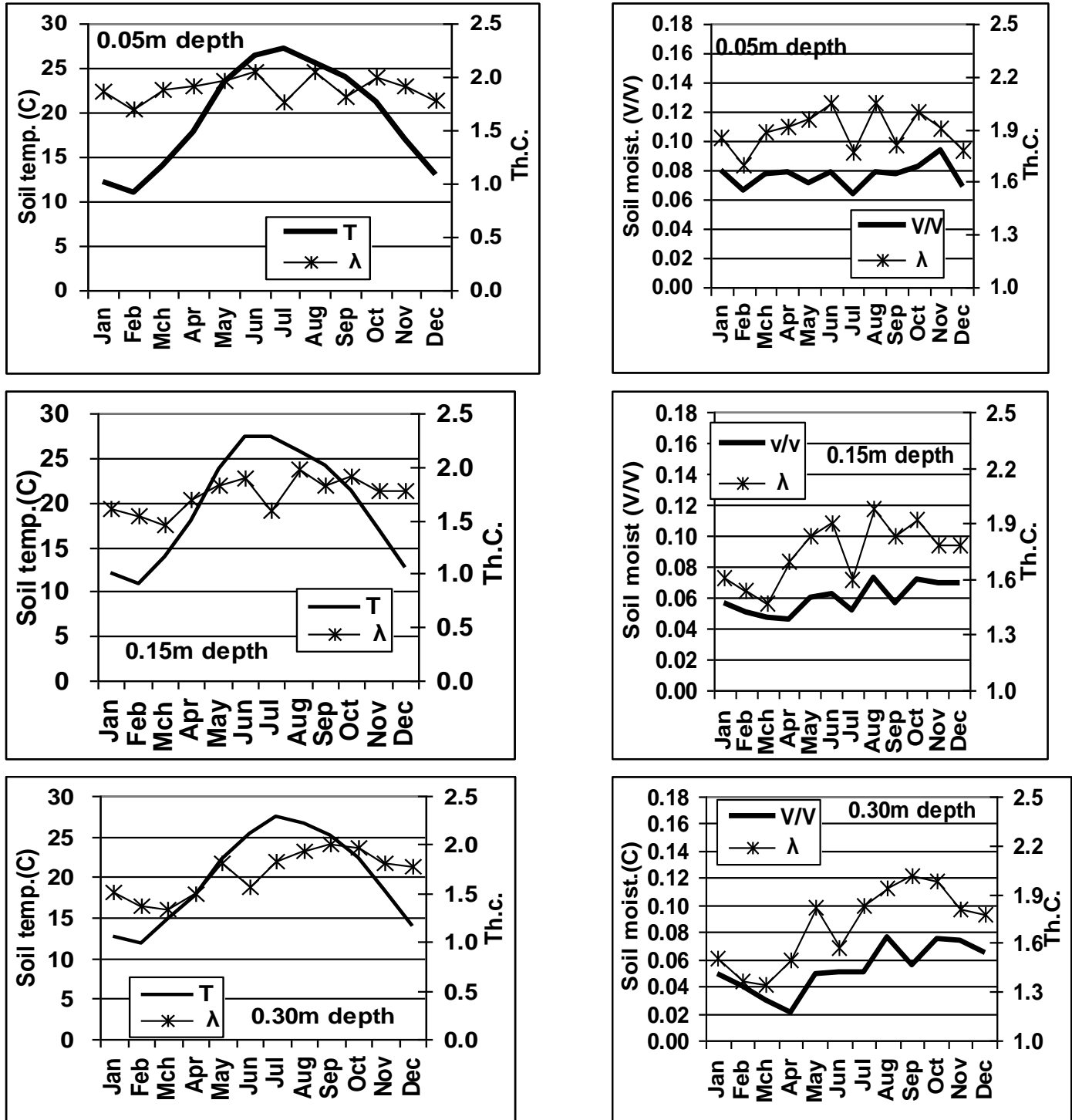

Fig. (4): Thermal conductivity (Th.C.) $\left(\mathrm{Jm}^{-1} \mathrm{~s}^{-1} \mathrm{c}^{-1}\right)$ (affected by soil temperature $\left.{ }^{\circ} \mathrm{C}\right)$ and soil moisture content $\left(\mathrm{m}^{3} / \mathrm{m}^{3}\right)$ through Twelve months from January to December at three depths (DOY=Day Of Year).

Fig.(5) shows the soil thermal conductivity for the three depths at 51 observations. The soil thermal conductivity at depth of $0.05 \mathrm{~m}$ was higher than at the other depths, until the day of year (DOY) of 167, after that it behaves similar for the other ones. That may be due to the effect of more volumetric moisture content on the thermal conductivity of the first five months of year than the other months.

Fayoum J. Agric. Res. \& Dev., Vol. 27, No.2, July, 2013 


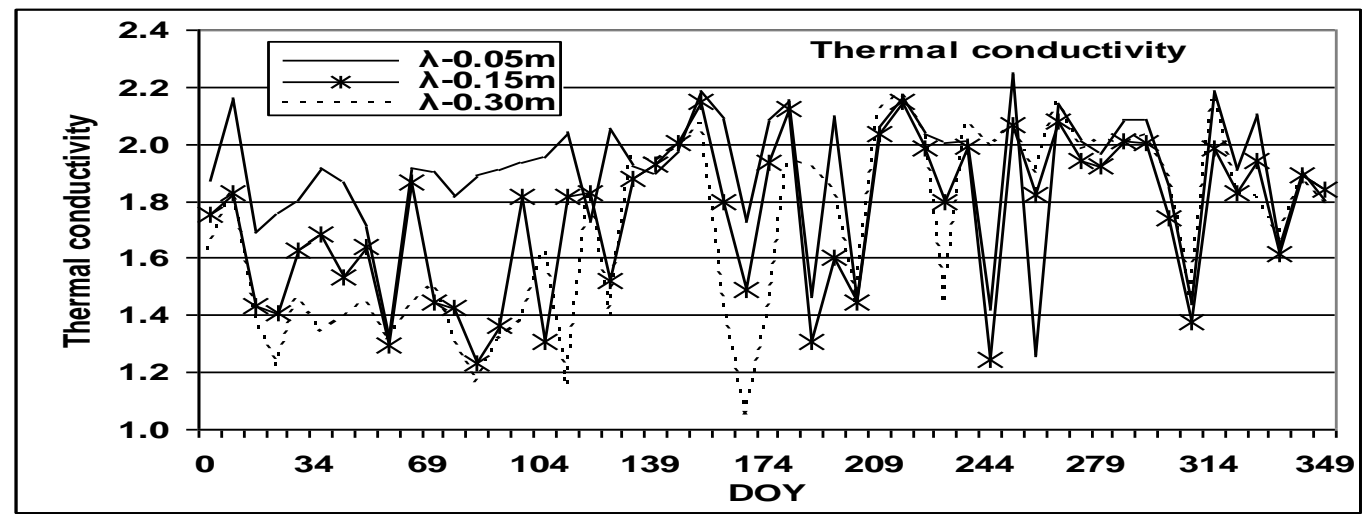

Fig. (5): thermal conductivity for three depths at 51 observations (DOY = Day of Year).

\section{3-Thermal diffusivity $\alpha)\left(\mathrm{m}^{2} \mathrm{~s}^{-1}\right)$ :}

Soil thermal diffusivity affected by soil temperature and soil volumetric moisture content similar as volumetric heat capacity and thermal conductivity. They ranged from 9.22592E-07 to 13.3223E-07, from 9.10083E-07 to $14.0327 \mathrm{E}-07$ and from $8.1068 \mathrm{E}-07$ to $15.1938 \mathrm{E}-07$ $\mathrm{m}^{2} \mathrm{~s}^{-1}$ at the three mentioned depths, respectively (table 13). Soil heat capacity and soil thermal diffusivity increase with increasing soil moisture content (Guan et al, 2009).

Table (13): Minimum, average and maximum values of thermal diffusivity $\left(\mathrm{m}^{2} \mathrm{~s}^{-1}\right)$ and $\left(\mathrm{m}^{2} \mathrm{day}^{-1}\right)$

\begin{tabular}{|c|l|c|c|c|}
\hline Depth (m) & & Minimum & Average & Maximum \\
\hline $0-0.05$ & $\mathrm{M}^{2} \mathrm{~s}^{-1}$ & $9.22592 \mathrm{E}-07$ & $12.0576 \mathrm{E}-07$ & $13.3223 \mathrm{E}-07$ \\
\cline { 2 - 5 } & $\mathrm{M}^{-}$day $^{-1}$ & 0.0797 & 0.1042 & 0.1151 \\
\hline $0.05-0.15$ & $\mathrm{M}^{-} \mathrm{s}^{-1}$ & $9.10083 \mathrm{E}-07$ & $11.6222 \mathrm{E}-07$ & $14.0327 \mathrm{E}-07$ \\
\cline { 2 - 5 } & $\mathrm{M}^{-}$day $^{-1}$ & 0.0786 & 0.1004 & 0.1212 \\
\hline $0.15-0.30$ & $\mathrm{M}^{-} \mathrm{s}^{-1}$ & $8.1068 \mathrm{E}-07$ & $11.5473 \mathrm{E}-07$ & $15.1938 \mathrm{E}-07$ \\
\cline { 2 - 5 } & $\mathrm{M}^{-}$day $^{-1}$ & 0.0700 & 0.0998 & 0.133 \\
\hline
\end{tabular}

Fig. (6) shows soil thermal diffusivity at the three depths verses 51 observation. The thermal diffusivity at soil depth of $0-0.05 \mathrm{~m}$ was higher than other depths until the day of year (DOY) of 167, after that it behaves similar to the other, while at soil depth of $0.15-0.3 \mathrm{~m}$ it showed scatter differences values than others, started from the above DOY .

Fayoum J. Agric. Res. \& Dev., Vol. 27, No.2, July, 2013 
THE EFFECT OF SOIL TEMPERATURE AND MOISTURE..........

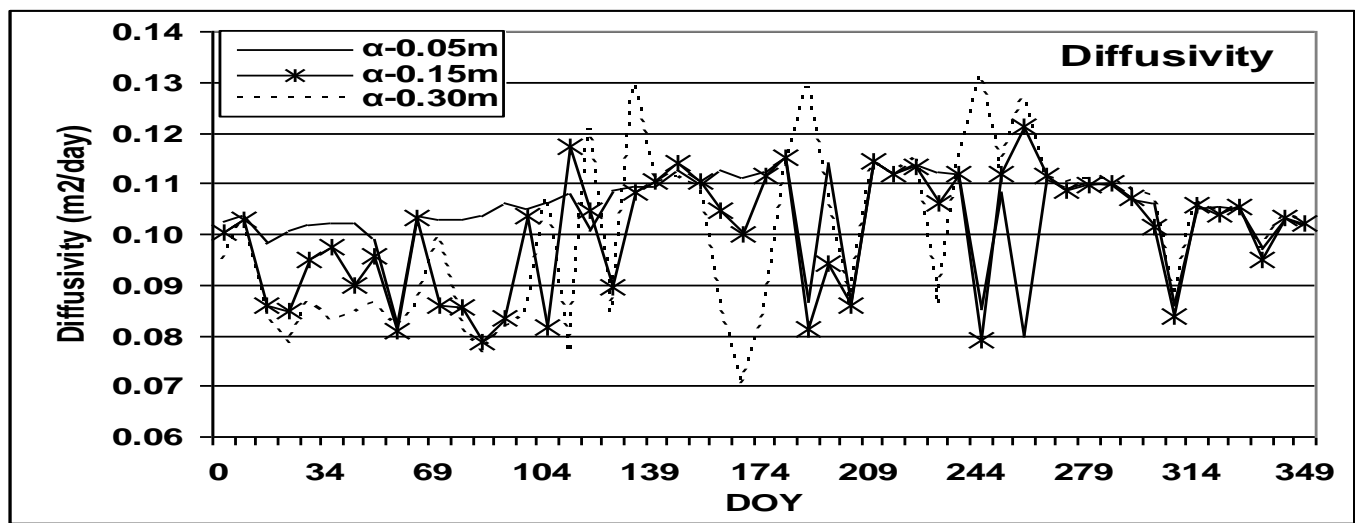

Fig. (6): Soil thermal diffusivity $\left(\mathrm{m}^{2} \mathrm{day}^{-1}\right)$ for three depths at 51 observation for three soil depths (DOY = Day Of Year).

\section{CONCLUSION}

Soil volumetric heat capacity and thermal conductivity considerations are characterized for sandy soil under sprinkler irrigation and specific Ismaili climatologically parameters which undertaken at Ismailia Agricultural Research Station. Volumetric heat capacity of 1.3 to $1.8 \mathrm{MJm}^{-3} \mathrm{c}^{-1}$ is characterized for sandy soil at moisture content of 0.51 to $7.89 \%$ for the same location. A soil temperature increased from 10 to $30^{\circ} \mathrm{C}$ at $0-0.30 \mathrm{~m}$ depth. There are increasing the thermal conductivity values nearly from 1.04 to $2.25 \mathrm{Jm}^{-1} \mathrm{~s}^{-1} \mathrm{c}^{-1}$ at the above water content, which temperature decreased with depth followed by thermal conductivity. Volumetric heat capacity and thermal conductivity calculated in sandy soil under similar temperature and water content can manage for suitable plant may cultivated in similar area.

\section{ACKNOWLEDGMENT}

The author wish to express his thanks to Prof. Dr. Samia M.S. ElMarsafawy for providing facilities and sincere help during this study.

\section{REFERENCES}

Abu-hamdeh, Nidal H. and Reeder, Randall C. (2000). Soil Thermal Conductivity: Effects of Density, Moisture, Salt Concentration, and Organic Matter. Soil Sci. Soc. Ame. J. V.64: (4): 1285-1290

Abd El-Dayem, A.O.A. (1999), The effect of soil temperature and soil moisture on the soil water movement. Ph.D. Sci. Degree of Agric, Fac. Of Agric. Moshtohor, Zagazig University.

Adjepong, S.K. (1997), Investigation of the variation of the specific heat capacity of three texture types of soil with moisture content. J. App. Sci. and Technology, (Ghana), 2 (1-2):7-12

Arshad, M.A. and Azooz, R.H. (1996), Tillage effects on soil thermal properties in a semiarid cold region. Soil Sci. Soc. Amer. J. 6: (2): 561-567.

Awadalla, S.Y. (1977), Studies on Egyptian calcareous soil "Thermal properties". Ph.D. Thesis . Fac. Agric. Cairo Univ. Egypt.

Fayoum J. Agric. Res. \& Dev., Vol. 27, No.2, July, 2013 
El-Raies, S.A.A.; et al

Bora, E.; Gupta, S.C. and Kosspwsli. J. (1990), Soil temperature predictions from numerical heat flow model using variable constant thermal diffusivity. Soils and Tillage Research, 1: 27-36.

De Vries, D.A. (1963), Thermal properties of soils, in "Physics of Plant Environment", W,R.Van Wijk (Ed.), North Holland, Amsterdam, 382pp.

Don Scott, H. (2000), Soil physics Agricultural and Environmental Applications.(ed.) Iowa State University press/Ames. USA.

Fritschen, I.J. and Gay, L.W. (1979), Environmental instrumentation. Springer-Verlag, NY. Inc. 216pp.

Guan S.; Huang J.; Guo Ni; Jianrong Bi. And Wang G. (2009), Variability of soil moisture and its relationship with surface albedo and soil thermal parameters over the loess plateau. Advances in Atmospheric Sciences, 26 (2):

Kersten, M.S. (1949), Thermal Properties of Soils. Bulletin 28, Engineering Experiment Station University of Minnesota Minneqpolis, MN.

Khalifa, H. El-H. M. (1992), Modeling coupled heat and moisture flow within a bare desert soil. Ph.D. Thesis, Dept. of Soil and Water Sci., Univ. of Arizona, USA.

Kimball, B.A.; Jackson, R.D.; Nakayama, F.S.; Idso, S.B. and Reginato, R.J. (1976), Soil heat flux determination: Temperature gradient method with computed thermal conductivities. J. Soil Sci. Soc. Am., 40: 25-28.

Klute A. (1986), Methods of Soil Analysis. Part1, Physical and Mineralogical Methods, Second edition No. 9 (part1) in the Series of Agronomy.

O'Donnell, J.A.; Romanovsky V.E.; Harden, J.W. and McGuire, A.D. (2009), The effect of moisture content on the thermal conductivity of mass and organic soil horizons from black spruce ecosystems in interior Alaksa. Soil Science, 174 (12): 646-651.

Page, A.L.; Miller, R.H. and Keeney, D.R. (1982), Methods of Soil Analysis Part II. Chemical and Microbiological Properties $2^{\text {nd }}$ ed. Agorn. Madison, Wisconsin. U.S.A.

Penner, E.; Johnston, G.H. and Goodrich, L.E. (1975), Thermal conductivity laboratory studies of some Mackenzie highway soil. Canadian Geotechnical Journal, :12: (3): 271-288.

Piper, C.S. (1950), Soil and Plant Analysis. Inter, Sci. Publ., Inc. N.Y. USA

Romanovsky V.E. and Osterjano T.E. (2000). Effect of unfrozen water on heat and mass transport processes in the active layer and permafrost. Permafr. Periglac. Process, 11: 219-239.

Sepaskhah, A.R. and Boersma, L. (1979), Thermal conductivity of soils as a function of temperature and water content. Soil Sci. Soc. Amer. J. 43 (3): 439-444 
THE EFFECT OF SOIL TEMPERATURE AND MOISTURE......... تأثير حرارة التربة والمحتوى الرطوبى على الخصائص الحراريه للأراضى الرملية

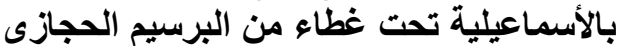

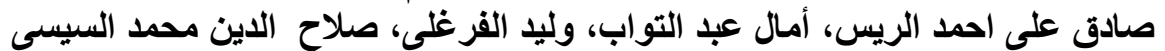

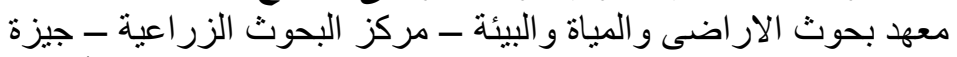

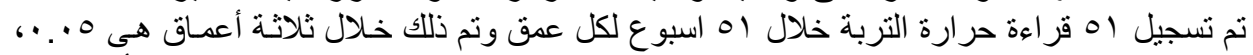

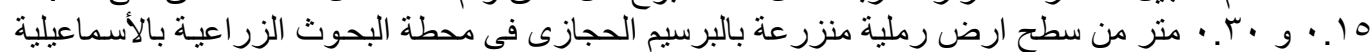

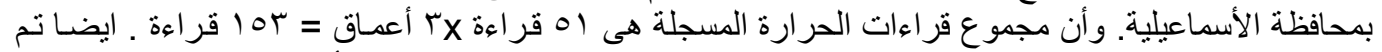

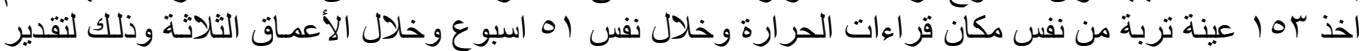

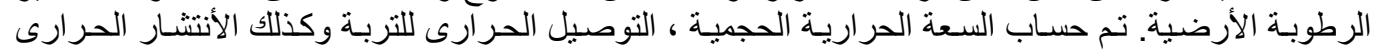

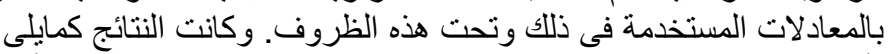

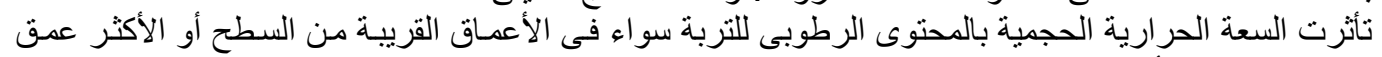

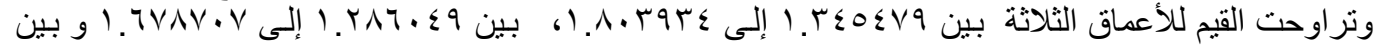

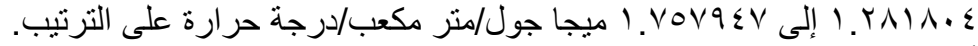

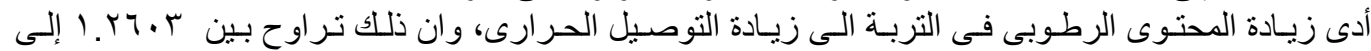

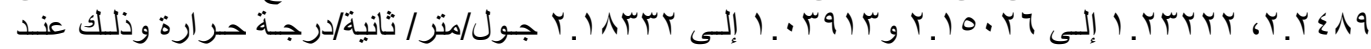

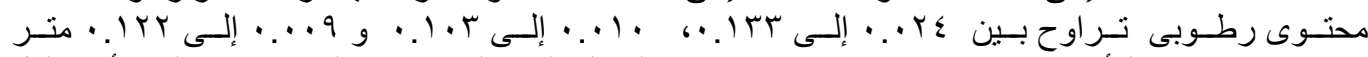

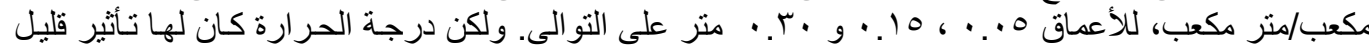

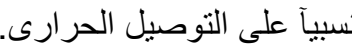

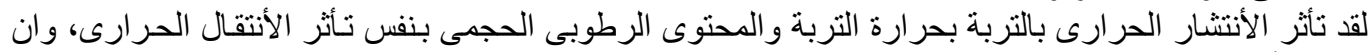

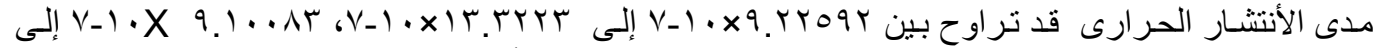

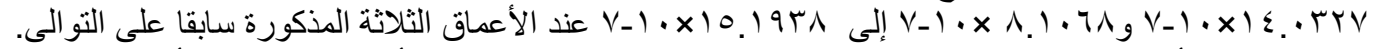

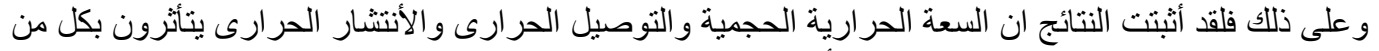

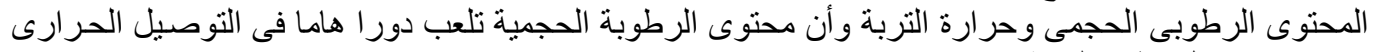
وانتشار ها خلال قطاع التربة.

Fayoum J. Agric. Res. \& Dev., Vol. 27, No.2, July, 2013 